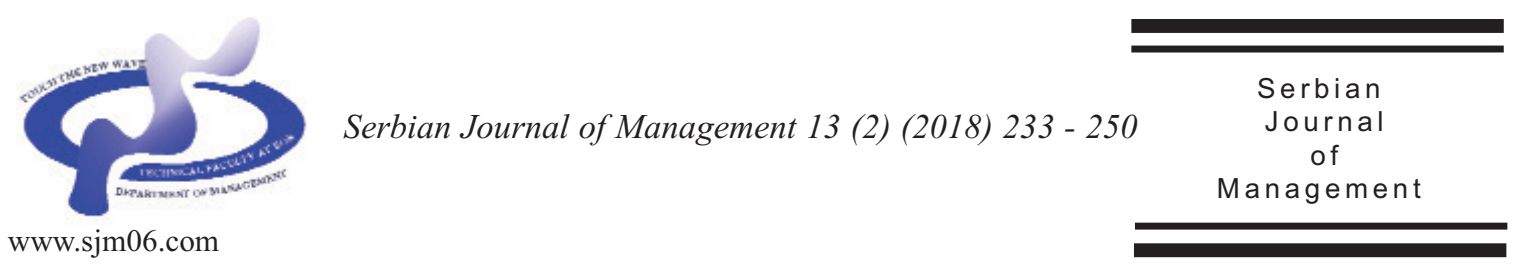

\title{
IMPACT OF JOB SATISFACTION ON PUBLIC SERVICE QUALITY: EVIDENCE FROM SYRIA
}

\author{
Elias Milana \\ Damascus University, Economics Faculty, Department of Business Administration, \\ Fawzi Al-Laham Street 9, Baramkeh 8, Damascus, Syria \\ (Received 8 May 2017; accepted 3 February 2018)
}

\begin{abstract}
Job satisfaction and Service quality are very important concepts that organizations must understand it in order to remain competitive and hence grow. It is very important for organizations to know how to measure these constructs in order to better understand their employees and customers. This study aims to highlight the job satisfaction and service quality. Also, identify the relationship between them in context of public sector - Syrian General Establishment for Insurance as a model. This study applied on a sample of (226) employees and (226) customers. The findings showed negative gaps between expect service and received service in all dimensions of quality and there is no significant correlation between job satisfaction and service quality of Syrian General Establishment for Insurance. In this context, this study is able to help public organization identify important areas for improvement.
\end{abstract}

Keywords: job catisfaction, cervice љиаlity, пublic cector, Syrian геneral establishment for unsurance, Syria

\section{INTRODUCTION}

Customer management is a main issue for various organizations, because of products and services is offered under the highly competitive and within international standards. It is not limited to private organizations, where public organizations have become more and more aware of the difficulty of business continuity in the modern market through the provision of services and goods by the old ways. In fact, it is noted that public organizations seek to improve its services through follow-up various changes and working to fit with them. There is a growing realization that it is not likely to improve quality of service and organizational performance and increase

\footnotetext{
* Corresponding author: emilana591@gmail.com
}

DOI: $10.5937 /$ sjm13-14734 
productivity without being the subject of satisfaction factor founder in the organization. Which means that public sector organizations can enhance their ability to manage customer satisfaction by paying more attention to the satisfaction of their employees.

Human resources should be considered the most important asset of an organization, because it would have a main role in achieving goals of organization. The key item of growth and development is manpower in each organization. Organizations could not affect the environment and wouldn't be successful in competition arenas, even if they had the best technologies or facilities, but they didn't have skilled and efficient employees. High quality of human resource means higher probability of organizational success (Savari et al., 2013).

All organizations must face up to the challenge of how to evaluate, utilize and develop the skills and capacities of their employees to ensure that organizational goals are achieved, also to ensure that individuals gain much satisfaction as possible from their jobs (Mguqulwa, 2008).

Organizations need to engage employees. Rapid market change, technologies, and opportunities available to main talent have forced organizations to reexamine the connections between business performance, job satisfaction and leadership. Over the past several years, many organizations have focused on reigning in main financial indicators. By searching the global labor market for the most efficient resources, using technology and creating process improvements to speed up operations, companies have created competitive advantages and improved financial performance. But outsourcing, downsizing, and off-shoring will soon reach upper limits on their capability to improve the organization's performance. In addition, these actions are available to all competitors, making them temporary sources of competitive advantage. While that, Human resource is permanent source of competitive advantage. Where, there is a direct correlation between employee satisfaction and job performance (Leimbach, 2006).

The public service needs to make better use of its most important resource (i.e. Human Resource) by providing the prospect of a career with a good employer, offering challenge and reward, by developing their skills to meet the managerial, technical and competitive challenges they face, and by ensuring equality of opportunity for their employees, irrespective of background, gender, race and disability (UN, 2005).

That perceptions of employees of the organization's commitment to them create feelings of obligation to the employer, which enhances work behavior of employees (Shore \& Wayne, 1993).

Job satisfaction represents several characteristics of a job situation such as the work itself, coworkers, pay and supervision. When the employees that feel they are being paid equitably and are being treated very well, they are likely to have positive attitudes towards the work. The employees are human resource or human capital. Human capital is viewed as an involvement and is often affected by management and relationships between employers and employees. When employees feel they are working much harder than others in the workplace but are not given equitable pay and not being treated well, they will likely have a negative attitude towards the job, the employer or coworkers. Thus, the employees may not be involved in their job (Akinbobola, 2011). 
The organization wishing to deliver good quality external services must first offer satisfying internal services that meet need of employees. Where there is positive and significant relationship between internal service quality and employee satisfaction (Wang, 2012).

A low level of job satisfaction may reduce the level of service performance. It is well known that there is a significant correlation between job satisfaction and service performance, which implies that the higher level of job satisfaction (Kim \& Han, 2013).

Noted Simonova et al. (2014) that planned career development in the public service organizations is limited, the chances of getting a promotion are remote and remote.

Within the above, the main purpose of this study theoretically is highlight the concepts of job satisfaction and service quality, and empirically identify level of service quality, and whether there is relationship between it and job satisfaction in the context of public service - Syrian General Establishment for Insurance as a model - Thus, this study seeks to answer the following questions:

1. Is there a negative gap between customers' expectations and customers' perceptions in Syrian General Establishment for Insurance?

2. What is the relationship between job satisfaction and service quality in Syrian General Establishment for Insurance?

\section{LITERATURE REVIEW}

\subsection{Job Satisfaction}

Job satisfaction is the individual's affective relations about his job role and is a function of the perceived relationship between what one wants from his job and what he perceives it is offering (Chazon, 2009).

Job satisfaction refers to the attitudes and feelings people about their work, favorable and positive attitudes towards the job indicate job satisfaction, unfavorable and negative attitudes towards the job indicate job dissatisfaction (Armstrong, 2006). job satisfaction is employee evaluation of his job, which is influenced by the location of employee at work, control of the work environment and incentive mechanism and management system (Arnett et al., 2002).

Since job is an important part of person's life, the relationship between job satisfaction and life satisfaction makes sense - one's job experiences spill over into one's life - a happy or unhappy life spills over into one's job evaluations and experiences. That organizations only have so much control over a person's job satisfaction, because for many people, their job satisfaction is a result, in part, of spillover of their life satisfaction. However, taking actions to improve low job satisfaction is not only important for organizational effectiveness, but by not doing so, organizations can cause spillover of employees' low job satisfaction into their life satisfaction. (Saari et al., 2004).

Job characteristics like autonomy, clarity of expected performance, task identity, skill variety and the like all promote job satisfaction. While organizational constraints, like insufficient budgetary support or shortage of resources, negatively affect job satisfaction. Employees' personalities too have been found to influence job satisfaction, as those with an internal locus of control are more satisfied with their jobs (Flap \& Völker, 2001).

Job satisfaction positively related with incentives, participation, organizational 
citizenship behavior, organizational commitment, life satisfaction, mental health, and work performance. It negatively associated with the volatility of the work, Absenteeism and the perceived pressure (Judge \& Hulin,1993). It can be controlled the customer satisfaction through fundamental factors of employees, this assumption is based on the idea that employees deliberately decide that find the satisfaction in their works and see it as worthy of attention. (MacDonald, 1996).

In same context, some studies emphasized the importance of individual innate dispositions in job satisfaction, while other studies highlighted the importance of situational factors such as characteristics of the job, work conditions, management practices, pay, tenure, relations with coworkers, and opportunities that work provides (Ozturk, 2010).

Customer satisfaction can be divided into intrinsic satisfaction which emphasized emotional and psychological aspects and extrinsic satisfaction which emphasized reward aspects. Intrinsic satisfaction means a sense of satisfaction from the inherent value of the work itself, such as the difficulty, diversity, challenging nature and importance of work, whereas extrinsic satisfaction means satisfaction with pay, fringe benefits, and working conditions, among others, which are provided externally according to job performance (Kim \& Han, 2013).

To measure customer satisfaction has been used many measures, ranging from a single-element scale to variety set of multielements scales. In sum, previous studies have generally emphasized the following factors: relationships with coworkers, relationships with supervisors, pay and benefits, workplace environments, performance assessments, and job contents.

\subsection{Service Quality}

Delivering service quality is considered and essential strategy for survival in contemporary competitive environment (Zeithaml et al., 1996). Service organizations have begun focusing on the customer perceptions of service quality because it helps in developing strategies that lead to customer satisfaction. there has been a shift from the focus on goods without much emphasis on services to a focus on services though paying attention on the goods. Service quality is very important because it leads to higher customer satisfaction, profitability, reduced cost, customer retention and loyalty (Daniel \& Berinyuy, 2010).

Service quality is defined as the discrepancy between consumers' perceptions of services offered by a particular organization and their expectations about organizations offering such services. Thus, when perceived service is less than expected service, it implies less than satisfactory service quality. But, when perceived service is less than expected service, the obvious inference is that service quality is more than satisfactory. Thus, while a negative discrepancy between perceptions and expectations causes dissatisfaction, a positive discrepancy leads to customer delight (Parasuraman et al., 1988).

The judgments of high and low service quality depend on how customers perceive the actual service performance in the context of what they expected. Thus, the key to ensuring good service quality is meeting or exceeding what customers expect from the service (Parasuraman et al, 1985).

SERVQUAL is one of the tools that are used in measuring the services quality. The originators of SERVQUAL are Parasuraman, 
Zeithamal and Berry. It was developed in 1985 but was polished in their subsequent articles in 1988. The key purpose of SERVQUAL is to have a standard and a reliable tool that can be used to measure services quality in different services sectors. Originally, SERVQUL's originators introduced ten service quality attributes, these are: tangibles, reliability, responsiveness, competency, courtesy, communication, credibility, security, access and understanding the customer. But in the 1988 article, these were pruned to five, these are: tangibles, reliability, responsiveness, assurance and empathy.

1. Tangibles: Appearance of physical facilities, equipment, personnel and written materials.

2. Reliability: Ability to perform the promised service dependably and accurately.

3. Responsiveness: Willingness to help customers and provide prompt service.

4. Assurance: Employees' knowledge and courtesy and their ability to inspire trust and confidence.

5. Empathy: Caring, easy access, good communication, customer understanding and individualized attention given to customers.

Parasuraman, Zeithaml and Berry identified a set of 22 items in the five different dimensions of service quality construct. Since they operationalized service quality as being a gap between expectations of customers and their perceptions of performance on these items, their service quality measurement scale is comprised of a total of 44 items (22 for expectations and 22 for perceptions).

Empirical evidence has indicated that success in service development requires a deep understanding of customer needs, expectations and preferences, and that marketing strategies implemented by organizations to expand internationally must take into account the different expectations and perceptions of customers (Aydin \&Yildirim, 2012).

The weakness of understanding or misunderstanding of customer expectations may cause problems related to resource allocation decisions (Chen \& Chang, 2005).

Also, customers perceptions of quality are considered pivotal as determinants of shopping behavior and product choice (Zeithaml, 1988).

Customer satisfaction is the result of his perception of received value in transaction. The customers form a perception of service quality according to service' performance that they experienced. Thus, through customer perception, he assesses the organization (Saeed et al., 2011).

\subsection{Job Satisfaction and Service Quality}

Job satisfaction can be considered as one of the main factors of organizations' efficiency and effectiveness. In fact the new managerial paradigm insists that it should be considered employees as human brain that have their own needs, wants and personal desires. A satisfied employee is a happy employee, and a happy employee is a successful employee (Aziri, 2011).

Satisfied employees are likely work hard and provide better services through organizational citizenship behavior. Satisfied employees tend to engage more in their organizations. They are more willing to provide high level of services quality (Yoon \& Suh, 2003).

Satisfied employees will offer personalized services that shall meet the customer satisfaction (Brian, 1999).

Satisfied employees are prerequisite to 
high service quality, because satisfied employee have more commitment for continuous improvement of quality (Mohsin \& Lockyer, 2010). Loyal employees are more able to provide a higher level of service quality (Silvestro \& Cross, 2000). Also, Hartline and Ferrell (1996) provided evidence that job satisfaction associated with the service quality.

The behavior which helps the organization to be successful is likely happen when employees are well motivated and feel committed to the organization and when the job gives them high levels of satisfaction (Armstrong, 2006).

Employees with higher levels of loyalty and commitment are considered one of the success indicators of organizations. This fact enhances efficiency and effectiveness of the organization performance. On the contrary, the behaviors of employees who are irresponsible will pass to others and reduce individual's performance and organization's quantity and quality (Savari et al., 2013).

Job satisfaction is very important for organizations. Its absence often leads to lethargy and reduced organizational commitment. Lack of job satisfaction is a predictor of quitting job (Tella et al., 2007).

Employee satisfaction is significantly associated to service quality and customer satisfaction, while the latter in turn influences organization profitability. Also, organization profitability has a moderate non-recursive effect on employee satisfaction, leading to a "satisfactionquality-profit cycle" (Yee et al., 2008).

On the other hand, Kim and Han (2013) found that job satisfaction partially affects the service quality. Also, Mathieu and Zajac (1990) concluded that employee satisfaction has little direct impact on business performance. While results Simpson (2006) did not show a significant relationship between job satisfaction and quality of service. Brown and Mitchell (1993) found that there was no significant relationship between the job satisfaction and customer satisfaction. Iaffaldano and Muchinsky (1985) found that the relationship between employee satisfaction and job performance is an illusory correlation, and they indicated that a perceived relation between two variables that intuitively think should exist, but in fact does not. In that same context, it is a commonly held belief that an increase in job satisfaction will result in improved performance, but research has not established any strongly positive connection between job satisfaction and performance (Armstrong, 2006).

It is not job satisfaction that leads to high performance but high performance that leads job satisfaction, and that a satisfied employee is not necessarily a productive employee and a high productive employee is not necessarily a satisfied employee. Persons are motivated to achieve certain goals and will be satisfied if they achieve these goals through improved performance. They maybe be even more satisfied if they are then rewarded by extrinsic recognition or an intrinsic sense of achievement. This suggests that improve performance can be achieved by giving individuals the opportunity to perform, ensuring that they have the knowledge and skill required to perform, and rewarding them by financial or non-financial means when they do perform. Also, that some persons may be complacently satisfied with their job and will not be inspired to work harder or better. They may find other ways to satisfy their needs (Armstrong, 2006).

The argument that employee satisfaction improves service quality is based on the 
theory of equity in social exchanges. The underlying assumption of equity in social exchanges is that most people expect social equity or justice to prevail in interpersonal transactions. An individual accorded some manner of social gifts that is inequitably in excess of what is anticipated will experience gratitude and feel an obligation to reciprocate the benefactor. Such positive reciprocal relationships evolve over time into trust, loyal, and mutual commitments. In the context of social exchange theory, when an employer offers favorable work conditions that make its service employees satisfied, the latter will in return tend to be committed to make an extra effort to the organization as means of reciprocity for their employer, leading to a higher level of service quality (Yee et al., 2008).

\subsection{Development of Hypotheses}

Many studies found negative gaps between customers' expected and perceived service. Martinovic et al., (2017) found that there is a significant negative gap between the perceived and expected quality of the public service. This leaded to conclusion that public organization should consider the importance of quality monitoring. Anderson (1995) assessed the quality of service provided by the clinic at the University of Houston Health Center, where it was found that patients were generally dissatisfied with the five dimensions of service quality. Ramseook-Munhurrun et al. (2010) measured quality of service provided by a major public sector department in Mauritius. It was found that all service quality gaps were negative. Kariru's and Aloo's study (2014) found that a gap exists between customers' expected and perceived service quality provided by hotels in the Western
Kenya tourism circuit in Kenya, the findings indicated that actual service was less than expected service. Also, through Daniel and Berinyuy's study (2010) in grocery stores in Umea-Sweden, it was found that all the service quality's dimensions showed a gap between expected service and perceived service. Thus the grocery stores need to make improvements in all dimensions in order to close gaps that could lead to increase customer satisfaction. Also, Asghari and Babu (2017) found that the customers' expectations were greater than their perceptions for all quality dimensions. Therefore level of service quality offered by healthy insurance companies at Bangalore city was low. Hence:

Hypothesis 1: There is a negative gap between customers' expectations and customers' perceptions.

Previous studies have provided some empirical support and theoretical backing that job satisfaction, service quality are likely to be associated with each other.

Employee satisfaction is crucial to achieve quality in the service industry (Yee et al., 2008). Satisfied employees are more willing to provide high level of service quality (Yoon \& Suh, 2003). Many studies have argued that service quality is influenced by job satisfaction (Hartline \& Ferrell, 1996; Ghayas \& Hussain, 2015; Kiragu, 2015). Hence:

Hypothesis 2: Job satisfaction has a positive influence on service quality.

\section{METHODOLOGY}

This study depends on the descriptive 
analytical method due to its relevance to the nature and objectives of the study.

This study was applied on employees and customers in Syrian General Establishment for Insurance. Where the Syrian General Establishment for Insurance acquires more than half of the Insurance market, with a market share of $(55 \%)$, and it employs more than (800) employees (www.sic.sy), it is affiliated to the Ministry of Finance. Sample of study is convenience. It included (226) employees for job satisfaction variable, and (226) customers for service quality variable. According to the limitations of the study, given the unique focus of this study that contributes to our understanding about relation between job satisfaction and service quality, we deem the topic is worthy of exploration despite the limitations on the sample size.

It was used a two-part questionnaire, the first one was used to measure job satisfaction. It was distributed to employees' sample and it was designed based on many previous studies, especially Simpson (2006) and Flap and Völker (2001). While the second one was used to measure service quality. It was distributed to customers' sample and it's based on SERVQUAL model which is subdivided into items, which were adjusted to measure service quality in The Syrian General Establishment for Insurance. As stipulated by the SERVQUAL model, the statements are divided into two parts, the first part seeks to measure expectations of customers, and the second part seeks to measure their perceptions.

The questionnaire was comprised of closed-ended questions. Each response was given a numerical score to reflect its degree of attitude. A five point Likert scale rating was employed, where the ratings indicated $1=$ strongly disagree, through to $5=$ strongly agree. Measure items were translated from English to Arabic and then back-translated from Arabic to English. Academicians from the department of Business Administration in Damascus University in Damascus were asked to evaluate the Arabic working. The questionnaire was piloted before was distributed. The pilot study involved (26) employees and (39) customers. The purpose of this procedure was guarantee good understanding and acceptance by respondents.

\section{THE RESULTS}

The demographic information (Table 1) provides general information about respondents on gender, age and level of education. This is to enable us get a better understanding of the type respondents and relate it to how they perceive service quality in The Syrian General Establishment for Insurance.

As table 1 exhibits, our respondents consist of (69.8\%) men and (30.2\%) women for employees' sample and consist of (61.4\%) men and (39.6\%) women for customers' sample. The majority of the respondents hold a bachelor's degree (41.9\%) for employees' sample, and Below or high school $(66.6 \%)$ for customers' sample, with age ranging above 50 years (65.97\%) for employees' sample, and with age ranging between 30 to less than 50 years (40.2\%) for customers' sample.

Checking the reliability, Cronbach's alpha was computed for job satisfaction measure and service quality measure. The internal consistency of job satisfaction items was assessed by computing the total reliability scale, the total reliability scale for study is $(0.868)$. This reliability value for our study is 
Table 1. Demographic Description

\begin{tabular}{llcc}
\hline Characteristics & Values & $\begin{array}{c}\text { \% Frequency For } \\
\text { Employees }\end{array}$ & $\begin{array}{c}\text { \% Frequency For } \\
\text { Customers }\end{array}$ \\
\hline Gender & Male & 69.8 & 61.4 \\
\multirow{4}{*}{ Age } & Female & 30.2 & 39.6 \\
& Below 30 years & 24.1 & 32.5 \\
\multirow{2}{*}{ Level of education } & 34.8 & 40.2 \\
& 30-50 years & 46.6 & 29.3 \\
& Above 50 years & 41.8 & 66.6 \\
& Below or high school & 41.9 & 31.2 \\
& Graduate & 15.3 & 2.2 \\
\hline
\end{tabular}

Table 2. The Reliability Scale for Job Satisfaction

\begin{tabular}{lcc}
\hline \multicolumn{1}{c}{ Item } & $\begin{array}{c}\text { Cronbach } \\
\text { Alpha If Item } \\
\text { Deleted }\end{array}$ & $\begin{array}{c}\text { Corrected } \\
\text { Item-Total } \\
\text { Correlation }\end{array}$ \\
\hline I feel I am being paid a fair amount for the work I do & .857 & .585 \\
There is really too little chance for promotion on my job & .859 & .540 \\
My supervisor is quite competent in doing his/her job & .859 & .524 \\
I am not satisfied with the benefits I receive & .856 & .601 \\
When I do a good job, I receive the recognition for it that I & .863 & .420 \\
should receive & .859 & .525 \\
I'm satisfied about our rules and procedures & .862 & .462 \\
I like the people I work with & .858 & .552 \\
I feel my job is useful & .862 & .466 \\
Those who do well on the job stand a fair chance of being & .858 & .542 \\
promoted & .855 & .620 \\
The benefit package we have is equitable & .864 & .414 \\
I feel a sense of pride in doing my job & .863 & .438 \\
I enjoy my coworkers & .862 & .372 \\
I like doing the things I do at work & .866 & .347 \\
The benefits we receive are as good as most other & .866 & .477 \\
organizations offer & .861 & .345 \\
The amount of work fits with the time available & .867 & \\
I feel that I know what is going on with the & & \\
organization & I feel satisfied with my salary &
\end{tabular}

substantial considering the fact that the highest reliability that can be obtained is 1.0 and this is an indication that the items of job satisfaction measure are accepted for analysis.

Table 2 shows the reliability scale for job satisfaction measure when each item is deleted from the measure and also corrected item-total correlation.

From table 2, it can be realized that all items show a lower value of reliability when any item deleted. Also, table 2 shows all values of the corrected item-total correlation increase (0.3).

The internal consistency of service quality items was assessed by computing the total reliability scale, the total reliability scale for the expected service by customers is (0.878), and for the actual service provided by the organization (0.858). This reliability value for our study is substantial considering the fact that the highest reliability that can be obtained is 1.0 and this is an indication that the items of service quality measure are 
accepted for analysis. Table 3 shows the reliability scale for service quality measure for both expectations and perceptions when each item is deleted from the measure and corrected item-total correlation.

From table 3, it can be realized that all items show a lower value of reliability when any item deleted. Also, table 3 shows all values of the corrected item-total correlation increase (0.3). Table 4 shows the reliability scale for quality dimensions (Expectations and perceptions) also, the reliability scale for each dimension calculated when each item is deleted, and the corrected item-total

Table 3. The Reliability Scale for Service Quality

\begin{tabular}{|c|c|c|c|c|}
\hline Item & $\begin{array}{l}\text { Cronbach } \\
\text { alpha if item } \\
\text { deleted for } \\
\text { expectations }\end{array}$ & $\begin{array}{l}\text { Cronbach } \\
\text { alpha if item } \\
\text { deleted for } \\
\text { perceptions }\end{array}$ & $\begin{array}{c}\text { Corrected } \\
\text { item-total } \\
\text { correlation for } \\
\text { expectations }\end{array}$ & $\begin{array}{c}\text { Corrected } \\
\text { item-total } \\
\text { correlation for } \\
\text { perceptions }\end{array}$ \\
\hline \multicolumn{5}{|l|}{ Tangibles } \\
\hline $\begin{array}{l}\text { The organization have up-to-date } \\
\text { equipments }\end{array}$ & .876 & .877 & .369 & .633 \\
\hline Physical facilities are visually appealing & .876 & .877 & .417 & .610 \\
\hline $\begin{array}{l}\text { Employees are well dressed and appear } \\
\text { neat }\end{array}$ & .877 & .882 & .368 & .423 \\
\hline \multicolumn{5}{|l|}{ Reliability } \\
\hline $\begin{array}{l}\text { When a customer has a problem, they } \\
\text { show a sincere interest in solving it }\end{array}$ & .872 & .878 & .503 & .560 \\
\hline $\begin{array}{l}\text { The organization perform the service right } \\
\text { the first time }\end{array}$ & .870 & .881 & .551 & .472 \\
\hline $\begin{array}{l}\text { The organization keep their records } \\
\text { accurately }\end{array}$ & .875 & .878 & .416 & .540 \\
\hline \multicolumn{5}{|l|}{ Responsiveness } \\
\hline $\begin{array}{l}\text { Employees make information easily } \\
\text { obtainable by customers }\end{array}$ & .875 & .876 & .436 & .646 \\
\hline $\begin{array}{l}\text { Employees give prompt service to } \\
\text { customers }\end{array}$ & .873 & .884 & .465 & .365 \\
\hline $\begin{array}{l}\text { Employees are always willing to help } \\
\text { customers }\end{array}$ & .876 & .882 & .375 & .412 \\
\hline $\begin{array}{l}\text { Employees are never too busy to respond } \\
\text { to customers requests }\end{array}$ & .867 & .879 & .641 & .515 \\
\hline \multicolumn{5}{|l|}{ Assurance } \\
\hline $\begin{array}{l}\text { The behavior of employees instill } \\
\text { confidence in customers }\end{array}$ & .875 & .881 & .407 & .471 \\
\hline $\begin{array}{l}\text { Customers feel safe in their transactions } \\
\text { with employees in the organization }\end{array}$ & .877 & .878 & .369 & .546 \\
\hline Employees are polite with customers & .872 & .877 & .519 & .573 \\
\hline $\begin{array}{l}\text { Employees of the organization have the } \\
\text { knowledge to answer customers' questions } \\
\text { Empathy }\end{array}$ & .867 & .884 & .644 & .394 \\
\hline $\begin{array}{l}\text { The organization give customers } \\
\text { individual attention }\end{array}$ & .875 & .883 & .399 & .404 \\
\hline $\begin{array}{l}\text { Their operating hours are convenient to all } \\
\text { their customers }\end{array}$ & .874 & .883 & .430 & .411 \\
\hline $\begin{array}{l}\text { Employees give customers personal } \\
\text { service }\end{array}$ & .871 & .873 & .568 & .662 \\
\hline $\begin{array}{l}\text { The organization have their customers' } \\
\text { best interest at heart }\end{array}$ & .862 & .878 & .829 & .547 \\
\hline $\begin{array}{l}\text { The employees understand the specific } \\
\text { need of their customer }\end{array}$ & .865 & .878 & .688 & .537 \\
\hline
\end{tabular}


Table 4. The Reliability Scale for Service Quality's Dimensions

\begin{tabular}{|c|c|c|c|c|c|c|}
\hline Dimensions & $\begin{array}{l}\text { Cronbach alpha } \\
\text { for dimensions } \\
\text { For expectations }\end{array}$ & $\begin{array}{l}\text { Cronbach alpha } \\
\text { for dimensions } \\
\text { For perceptions }\end{array}$ & $\begin{array}{l}\text { Cronbach } \\
\text { alpha if item } \\
\text { deleted for } \\
\text { expectations }\end{array}$ & $\begin{array}{c}\text { Cronbach } \\
\text { alpha if item } \\
\text { deleted for } \\
\text { perceptions }\end{array}$ & $\begin{array}{l}\text { Corrected } \\
\text { item-total } \\
\text { correlation for } \\
\text { expectations }\end{array}$ & $\begin{array}{c}\text { Corrected } \\
\text { item-total } \\
\text { correlation for } \\
\text { perceptions }\end{array}$ \\
\hline & \multirow{4}{*}{.820} & \multirow{3}{*}{.850} & .733 & .772 & .693 & .740 \\
\hline \multirow{3}{*}{ Tangibles } & & & .715 & .760 & .710 & .752 \\
\hline & & & .805 & .838 & .621 & .669 \\
\hline & & \multirow{4}{*}{.886} & .764 & .797 & .802 & .826 \\
\hline \multirow[t]{4}{*}{ Reliability } & \multirow[t]{4}{*}{.867} & & .816 & .840 & .744 & .775 \\
\hline & & & .858 & .876 & .698 & .735 \\
\hline & & & .793 & .827 & .666 & .724 \\
\hline & & \multirow{4}{*}{.867} & .788 & .829 & .678 & .720 \\
\hline \multirow[t]{3}{*}{ Responsiveness } & \multirow[t]{3}{*}{.836} & & .794 & .828 & .664 & .722 \\
\hline & & & .797 & .836 & .658 & .703 \\
\hline & & & .788 & .822 & .685 & .738 \\
\hline \multirow{3}{*}{ Assurance } & \multirow{3}{*}{.838} & \multirow{3}{*}{.867} & .801 & .837 & .656 & .701 \\
\hline & & & .807 & .837 & .644 & .704 \\
\hline & & & .784 & .826 & .695 & .731 \\
\hline \multirow{5}{*}{ Empathy } & \multirow{5}{*}{.810} & \multirow{5}{*}{.817} & .739 & .747 & .710 & .720 \\
\hline & & & .786 & .795 & .553 & .559 \\
\hline & & & .794 & .800 & .527 & .542 \\
\hline & & & .745 & .756 & .686 & .688 \\
\hline & & & .796 & .802 & .518 & .534 \\
\hline
\end{tabular}

Table 5 Show Summery of Means of Job Satisfaction

\begin{tabular}{lcc}
\multicolumn{1}{c}{ Item } & Mean & Std. Deviation \\
\hline I feel I am being paid a fair amount for the work I do & 3.2485 & .92632 \\
There is really too little chance for promotion on my job & 2.8681 & .84002 \\
My supervisor is quite competent in doing his/her job & 3.1043 & 1.02650 \\
I am not satisfied with the benefits I receive & 2.9356 & .92428 \\
When I do a good job, I receive the recognition for it that I & 3.0890 & .84929 \\
should receive & 2.6748 & .95036 \\
I'm satisfied about our rules and procedures & 3.5337 & .89979 \\
I like the people I work with & 2.9816 & .90109 \\
I feel my job is useful & 3.2853 & .85659 \\
Those who do well on the job stand a fair chance of being & 3.1687 & 1.02540 \\
promoted & 3.0767 & 1.00626 \\
The benefit package we have is equitable & 3.0644 & 1.00406 \\
I feel a sense of pride in doing my job & 3.0890 & .90540 \\
I enjoy my coworkers & 3.1718 & .97410 \\
I like doing the things I do at work & & 1.10751 \\
The benefits we receive are as good as most other & 3.2025 & .94833 \\
organizations offer & & .84040 \\
The amount of work fits with the time available & 2.7669 & .97195 \\
organization & 2.2178 & \\
I feel satisfied with my salary & 3.1564 & \\
The goals of this organization are not clear to me & The overall average job satisfaction $=3.0353$ & \\
\hline
\end{tabular}

correlation.

From table 4, it can be realized all the items show a lower value of reliability when deleted. Also, shows that all values of corrected item-total correlation increase (0.3). Table 5 shows summary of means and 
std. deviation of job satisfaction.

As shown in Table 5, the Means of Job Satisfaction were established. Items with the highest mean scores are: "I like the people I work with", "Those who do well on the job stand a fair chance of being promoted", "I feel I am being paid a fair amount for the work I do" and "My supervisor is quite competent in doing his/her job". This indicates that the employees felt that Establishment paid more attention to these items. However items such as "I feel satisfied with my salary" and "I'm satisfied about our rules and procedures" have the lowest mean scores. And this shows that the employees felt that the establishment paid less attention to these items.

Generally, notes from the above table that the employees of The Syrian General Establishment for Insurance are generally not satisfied (3.0353), all items of job satisfaction did not exceed the average of measure. Thus this reflects dissatisfaction.

Table 6 show summary of means of customers' expectations and perceptions, and gaps scores.

As shown in Table 6, the customers' expectations were established. Items with the highest mean scores are: "Employees of the organization have the knowledge to answer customers' questions", "The organization keep their records accurately", "Employees are polite with customers" and "Their operating hours are convenient to all their customers". This indicates that customers expected for these items more than the other items. However, "Employees are well dressed and appear neat" and "Employees give customers personal service" have the lowest mean scores. This indicates that customers expected these items less than the other items. This can be explained by the customers understanding that no human can be perfect and errors may be inevitable.

As illustrated in Table 5, the customers' perceptions were established. Items with the highest mean scores are: "The organization perform the service right the first time", "The organization give customers individual attention" and "Employees of the organization have the knowledge to answer customers' questions". This indicates that the customers felt that the establishment paid more attention to these items in service delivery. However items such as "The organization have up-to-date equipments", "Employees give prompt service to customers" and "The organization have their customers' best interest at heart" have the lowest mean scores. This shows that the customers felt that the establishment paid less attention to these factors.

Service quality is the difference between customers' expectations and perceptions of service (Parasuraman et al., 1985). I.e. it is also meeting and exceeding customers' expectations, thus, the goal of every organization should be to minimize the gap between customers' expectations and perceptions of service quality.

As shown in Table 5, the quality gap was calculated as well. The findings indicate that actual service was less than expected service in all the items apart from the item "Employees are well dressed and appear neat" (gap score $=0.12$ ), The largest gaps scores, which indicate the poorest service quality are: " Their operating hours are convenient to all their customers", "knowledge to answer customers' questions" and "Employees are polite with customers". This means that for the establishment to meet their customers' expectations, it needs to pay more attention to these items. For example, the establishment may have to train their employees on service delivery and customer 
Table 6. Summary of Means of Customers' Expectations and Perceptions, And Gap Scores

\begin{tabular}{|c|c|c|c|c|}
\hline Item & $\begin{array}{l}\text { Expectations } \\
\text { Score }\end{array}$ & $\begin{array}{l}\text { Perceptions } \\
\text { Score }\end{array}$ & $\begin{array}{l}\text { Gap } \\
\text { Score }\end{array}$ & $\begin{array}{l}\text { AvgGap } \\
\text { score }\end{array}$ \\
\hline Tangibles & & & & -.83 \\
\hline The organization have up-to-date equipments & 3.4233 & 2.0031 & -1.42 & \\
\hline Physical facilities are visually appealing & 4.0123 & 2.8221 & -1.19 & \\
\hline Employees are well dressed and appear neat & 3.1902 & 3.3067 & .12 & \\
\hline Reliability & & & & -.88 \\
\hline $\begin{array}{l}\text { When a customer has a problem, they show a sincere } \\
\text { interest in solving it }\end{array}$ & 3.6595 & 3.0429 & -.62 & \\
\hline The organization perform the service right the first time & 4.4479 & 3.5859 & -.86 & \\
\hline The organization keep their records accurately & 4.5675 & 3.3957 & -1.17 & \\
\hline Responsiveness & & & & -1.18 \\
\hline $\begin{array}{l}\text { Employees make information easily obtainable by } \\
\text { customers }\end{array}$ & 3.9632 & 2.8006 & -1.16 & \\
\hline Employees give prompt service to customers & 3.9448 & 2.5399 & -1.40 & \\
\hline Employees are always willing to help customers & 3.9018 & 2.7791 & -1.12 & \\
\hline $\begin{array}{l}\text { Employees are never too busy to respond to customers } \\
\text { requests }\end{array}$ & 3.8252 & 2.7853 & -1.04 & \\
\hline Assurance & & & & -1.25 \\
\hline $\begin{array}{l}\text { The behavior of employees instill confidence in } \\
\text { customers }\end{array}$ & 4.0920 & 2.9724 & -1.12 & \\
\hline $\begin{array}{l}\text { Customers feel safe in their transactions with } \\
\text { employees in the organization }\end{array}$ & 4.3129 & 3.2209 & -1.09 & \\
\hline Employees are polite with customers & 4.5583 & 3.1963 & -1.36 & \\
\hline $\begin{array}{l}\text { Employees of the organization have the knowledge to } \\
\text { answer customers' questions }\end{array}$ & 4.8620 & 3.4325 & -1.43 & \\
\hline Empathy & & & & -.75 \\
\hline The organization give customers individual attention & 3.6043 & 3.5092 & -.10 & \\
\hline $\begin{array}{l}\text { Their operating hours are convenient to all their } \\
\text { customers }\end{array}$ & 4.5092 & 2.9755 & -1.53 & \\
\hline Employees give customers personal service & 3.2393 & 3.1595 & -.08 & \\
\hline $\begin{array}{l}\text { The organization have their customers' best interest at } \\
\text { heart }\end{array}$ & 3.4141 & 2.5644 & -.85 & \\
\hline $\begin{array}{l}\text { The employees understand the specific need of their } \\
\text { customer }\end{array}$ & 4.4387 & 3.2515 & -1.19 & \\
\hline \multicolumn{5}{|c|}{ Overall average gap score $=-0.9802$} \\
\hline
\end{tabular}

relationship management in order to enhance their relations with customers. The findings further show that actual service is less than expected service in all quality dimensions (tangibles $=-0.83, \quad$ reliability $=-0.88$, responsiveness $=-1.18$, assurance $=-1.25$ and empathy=-0.75). Empathy have the lowest service gap followed by tangibles, reliability, responsiveness then assurance. This suggests that The Syrian General Establishment for Insurance needs to improve their service quality by probably focusing more on the tangibles aspect of quality of service and training employees in order to improve their responsiveness, assurance, understanding, and dependability.

However, Overall average gap score $=$ 0.9802 and One-sample $\mathrm{T}$ test for overall service quality gap is showed that the difference between service quality gap and value $=0$ is significant difference (Sig (2tailed $)=0.000$ ). This leads to approval of the first hypothesis.

However, table 5 shows that customer expectations are not very high, this indicates that customers do not expect high performance of establishment. This can be attributed to past experiences and information received about this public organizations was not good, which is 
common in developing countries. From the above, it can be realized that customers' expectations are more than their perceptions, this indicates customers are not satisfied with service quality. Therefore, means that The Syrian General Establishment for Insurance need to make improvements to close gap that could lead to increased customer satisfaction. Thus, Syrian public service quality is need to a necessary improvement and development. Table 7 shows results of correlation analysis between job satisfaction and service quality.

Table 7. Results of Correlation Analysis between Job Satisfaction and Service Quality

\begin{tabular}{llr}
\hline Variable & & Service Quality \\
\hline Job Satisfaction & Pearson Correlation & -0.233 \\
& Sig. (2-tailed) & 0.352 \\
\hline
\end{tabular}

From the above it can be concluded that there is no significant correlation between job satisfaction and service quality in The Syrian General Organization for Insurance. This leads to disapproval of the second hypothesis.

\section{CONCLUSIONS}

The study findings are based on data was collected from a public organization in Syria (The Syrian General Establishment for Insurance).

The study found the overall service quality is low. Customers have higher expectations than what they actually receive from the establishment. The findings showed negative gaps between expect service and received service for all dimensions of quality. The service quality gaps indicated that the establishment was failing to meet the expectations of their customers.

This result is congruent with many studies that found negative gaps in all quality's dimensions (as Anderson, 1995; Daniel \& Berinyuy, 2010; Ramseook-Munhurrun et al., 2010; Kariru \& Aloo, 2014; Asghari \& Babu, 2017; Martinovic et al., 2017).

Also, this study found that there is no significant correlation between job satisfaction and service quality in The Syrian General Establishment for Insurance. This result is congruent with many studies that hadn't found a significant relationship to build on (as Iaffaldano \& Muchinsky, 1985; Brown \& Mitchell, 1993; Armstrong, 2006; Simpson, 2006). Thus, this result differ from previous studies that have shown a significant relationship between job satisfaction and service quality (as Hartline \& Ferrell, 1996; Yoon \& Suh, 2003; Yee et al., 2008; Ghayas \& Hussain, 2015; Kiragu, 2015).

The Syrian General Establishment for Insurance is one of public sector organizations. There is a general realization of the importance of develop and improve regulations, laws, techniques and methods are used. This fact does not support highlevel expectations of service provided, and service experiences do not change customers expectations about public service. Thus, the level of both expected and actual service is not high. Faced with this reality, job satisfaction does not play an important role in service quality. In other words, the employees have done their tasks without paid attention to achieve customers satisfaction, that is because of the low level of job satisfaction and the weakness of laws and procedures that drive attention to customer satisfaction. The customers have gotten the service without expecting any improve, i.e. they have accustomed to 
provide service quality. In sum, in this bureaucratic framework, the work is done, services are provided without any change. Thus, both of job satisfaction and service quality act independently, under laws and regulations are unable to adjust their movement. In the end, all parties are dissatisfied. Thus, it is necessary for The Syrian General Organization for Insurance makes efforts to change this reality. In this context, this study is able to help this public organization to identify important areas for improvement in its service.

\section{LIMITATIONS}

There are some limitations associated with this study, the results obtained from this study cannot be generalized to a wide range of similar situations concerning public organization because of related to issue of sample size, where, This study applied in The Syrian General Establishment For Insurance, with taking into account the laws and regulations in this organization and its impact on study sample.

Also, it can be said that the recessionary trends being faced currently might have some influence on the satisfaction levels. The responses have been solicited from customers in a developing economy.

However, the above limitations are less significant compared to the importance of carrying out this type of study. Such a study should be carried out frequently in order to monitor job satisfaction and service quality, hence make necessary adjustments in case of any weaknesses or strengths.

\section{References}

Akinbobola, O.I. (2011). Conflict in human capital relationships: the impact of job satisfaction on job involvement in a workplace. International Journal of Social Science and Humanity, 1(2), 92-95.

Anderson, E. (1995). Measuring service quality at a university health clinic. International journal of health care quality assurance, 8(2), 7-32.

Armstrong, M. (2006). A Handbook of Human resource Management Practice, Tenth Edition, Kogan Page Publishing, London.

Asghari, M., \& Babu, S. (2017). Understanding of customer Expectations and perceptions of India healthy insurance companies. International Journal of Engineering Trends and Technology, 43(3), 138-146.

Arnett, D.B., Laverie, D.A., \& McLane, C. (2002). Using job satisfaction and pride as internal-marketing tools. The Cornell Hotel and Restaurant Administration Quarterly, 43(2), 87-96.

Aydin, K., \& Y1ldırım, S. (2012). The measurement of service quality with servqual for different domestic airline firms in Turkey. Serbian Journal of Management, 7(2), 219-230.

Aziri, B. (2011). Job satisfaction, a literature review. Management Research and Practice, 3(4), 77-86.

Brian P. (1999). Yesterday, today and tomorrow. The lifecycle of the UK funeral Industry. Mortality, 4(2), 127-145.

Brown, K.A., \& Mitchell, T.R. (1993), Organizational obstacles: links with financial performance, customer satisfaction, and job satisfaction in a service environment. Human Relations, 46 (6), 725-75.

Chazon, T.L. (2009). Social Capital: 
Relationship between Social Capital and teacher job satisfaction within a Learning Organization, Doctoral dissertation, Gardner-Webb University.

Chen, F.Y., \& Chang, Y.H. (2005). Examining airline service quality from a process perspective. Journal of Air Transport Management, 11(2), 79-87.

Daniel, C., \& Berinyuy, L. (2010). Using the SERVQUAL Model to assess Service Quality and Customer Satisfaction.: An Empirical Study of Grocery Stores in Umea, Master dissertation, Umea University.

Flap, H., \& Völker, B. (2001). Goal specific social capital and job satisfaction: Effects of different types of networks on instrumental and social aspects of work. Social networks, 23(4), 297-320.

Ghayas, M., \& Hussain, J. (2015). Job satisfaction, service quality and the customer satisfaction in the IT sector of Karachi. International E-Journal of Advances in Social Sciences, 1(3), 443-451.

Hartline, M.D., \& Ferrell, O.C. (1996). The management of customer-contact service employees: An empirical investigation. Journal of Marketing, 60(4), 52-70.

Iaffaldano, M.T., \& Muchinsky, P.M. (1985). Job satisfaction and job performance: A meta-analysis. Psychological bulletin, 97(2), 251.

Judge, T.A., \& Hulin, C L. (1993). Job satisfaction as a reflection of disposition: A multiple source causal analysis. Organizational Behavior and Human Decision Processes, 56(3), 388-421.

Kariru, A., \& Aloo, C., (2014). Customers' perceptions and expectations of service quality in hotels in western tourism circuit, Kenya. Journal of Research in Hospitality, Tourism and Culture, 2(1), 1-12. Kim, P., \& Han, J. H. (2013). Effects of job satisfaction on service quality, customer satisfaction, and customer loyalty: The case of a local state-owned enterprise. WSEAS Transactions on Business and Economics, 1(10), 49-68.

Kiragu, F.K. (2015). Relationship between employee satisfaction and service quality: a survey of funeral homes in Nairobi City County, Master Thesis, University Of Nairobi.

Leimbach, M. (2006). Redefining Employee Satisfaction: Business Performance, Employee Fulfillment, and Leadership Practices. research report, Wilson learning Worldwide Inc.

MacDonald, R. (1996). Labours of love: Voluntary working in a depressed local economy. Journal of Social Policy, 25(1), 1938.

Martinovic, M., Pavlic, I., \& Tolic, M. (2017). Measurement of local public services' quality using SERVQUAL: the case of Dubrovnik, Economic Thought and Practice, 2, 593-610.

Mathieu, J.E. \& Zajac, D.M. (1990) A review and meta-analysis of the antecedents, correlates, and consequences of organizational commitment. Psychological Bulletin, 108 (2), 171-194.

Mguqulwa, N. (2009). The relationship between organizational commitment and work performance in an agricultural company, Doctoral dissertation, University so South Africa.

Mohsin A., \& Lockyer, T. (2010). Customer's perception of service quality in luxury hotels in New Delhi, India: an exploratory study. International Journal of Contemporary Hospitality Management. 22(2), 160-173.

Ozturk, F. (2010). Determinants of organizational citizenship behavior among knowledge workers: the role of job 


\title{
УТИЦАЈ ЗАДОВОЉСТВА ПОСЛОМ НА КВАЛИТЕТ ЈАВНИХ УСЛУГА: ПРИМЕР ИЗ СИРИЈЕ
}

\author{
Elias Milana
}

\section{Извод}

Задовољство послом и квалитет услуге су врло важни концепти које организације морају разумети како би остале конкурентне и самим тиме расле. Веома је важно да организације знају како измерити ове конструкте како би боље разумеле своје запослене и купце. Ово истраживање има за циљ да нагласи задовољство послом и квалитет услуга. Такође, идентификује однос између њих у контексту јавног сектора - где је Сиријска генерална цлужба за осигурање узета као модел . Ово истраживање спроведено је на узорку (226) запослених и (226) купаца. Резултати су показали негативне разлике између очекиване услуге и примљене услуге у свим димензијама квалитета и не постоји значајна корелација између задовољства послом и квалитета услуге Сиријске генералне цлужбе за осигурање. У овом контексту, ова студија може да помогне јавној организацији да идентификује важна подручја за побољшање.

Кључне речи: задовољство послом, квалитет услуге, јавни сектор, Сиријска генерална цлужба за осигурање, Сирија

charcteristics, job satisfaction, and Saeed, I., Niazi, M.A., Arif, M., \& Jehan, organizational commitment, Doctoral N. (2011). Antecedents of Customer dissertation, Middle East Technical satisfaction and its outcomes A study of University.

Parasuraman, A., Zeithaml, A., \& Berry, L. (1985). A conceptual model of service quality and its implications for future research. Journal of Marketing, 49(4), 41-50.

Parasuraman, A., Zeithaml, A., \& Berry, L. (1988). SERVQUAL: a multiple-item scale for measuring consumer perceptions of service quality. Journal of Retailing, 64(1), 12-40.

Ramseook-Munhurrun, P., Desai LukeaBhiwajee, S., \& Naidoo, P. (2010). Service quality in the public service, International Journal of Management and Marketing Research, 3(1), 37-50.

Saari, L.M., \& Judge, T.A. (2004). Employee attitudes and job satisfaction. Human resource management, 43(4), 395407. Pakistani service sector. Interdisciplinary Journal of Contemporary Research in Business, 3(8), 877-889.

Savari, M., Eslami, M., \& Monavarifard, F. (2013). The Impact of Social Capital on Agricultural Employees' Job Satisfaction, City of Divandarreh. International Research Journal of Applied and Basic Sciences, 4(2), 291-295.

Shore, L.M., \& Wayne, S.J. (1993). Commitment and employee behavior: comparison of affective commitment and continuance commitment with perceived organizational support. Journal of applied psychology, 78(5), 774-780.

Silvestro, R., \& Cross, S. (2000). Applying the service profit chain in a retail environment: Challenging the "satisfaction mirror". International Journal of Service 
Industry Management, 11(3), 244-268.

Simonova, M., Bruna, S., \& Ilmete, Z. (2014). New approaches to human capital development in public administration in Latvia. European Integration and Baltic Sea Region: Diversity and Perspectives, Conference Paper.

Simpson, E.P. (2006). Examining employee satisfaction, customer service and customer satisfaction in a retail banking organization, Doctoral dissertation, University of North Texas.

Tella, A., Ayeni, O., \& Popoola, O. (2007). Work motivation, job satisfaction, and organizational commitment of library personnel in academic and research libraries in Oyo State, Nigeria. Library philosophy and practice, 9(2), 13.

United Nations. (2005). Human resources for effective public administration in a globalized world, New York: Department of Economic and Social Affairs.

Yee, R.W., Yeung, A C., \& Cheng, T.E. (2008). The impact of employee satisfaction on quality and profitability in high-contact service industries. Journal of operations management, 26(5), 651-668.

Yoon, M.H., \& Suh, J. (2003). Organizational citizenship behaviors and service quality as external effectiveness of contact employees. Journal of Business Research, 56(8), 597-611.

Zeithaml A. (1988). Consumer perceptions of price, quality, and value: A means-end model and synthesis of evidence. Journal of Marketing, 52(3), 2-22.

Zeithaml, A., Berry, L., \& Parasuraman, A. (1996). The behavioral consequences of service quality. Journal of Marketing, 60(2), 31-46.

Wang, G.L. (2012). The influence of internal service quality on employee job satisfaction at Taiwan listed international tourist hotels: using organisational culture as the moderator. World Transactions on Engineering and Technology Education, 10(3), 174-183.

Website of The Syrian General Establishment for Insurance, http://www.sic.sy/. 